も，十分精度の高い特性曲線が得られることがわかった。 これは, DSAでは，相反則不軌の影響がないためであ る.また, boot・strap 法においても, ビームハードニン グ・トレンド・ベーリンググレア等を考慮に入れれば, time・scale 法に匹敵した，精度の高い特性曲線が得ら れることがわかった。

\section{3. 周波数サブトラクションの腹部アンギオへの応用}

国立がんセンター

○関口雅幸・阿南充洋・半村勝浩

野畑 強・宮岡裕子

腹部アンギオをサブトラクション処理する場合に扔い て，ガス影のムービング・アーチファクトにより血管影 が不明瞭になることがある.このムービング・アーチフ アクトを画像処理によって消去することができれば，腹 部アンギオにとって有効なものになると考える. 問題と なるガス影は血管影に対し低周波成分である，そこで原 画像よりボケ画像をサブトラクションし，低周波成分を カットするという周波数サブトラクション法を試みた。

〔結果〕周波数サブトラクションによっても，通常の サブトラクションに近い，あるいは同等に血管影を描出 することが可能であり，特に今回目的としたムービン グ・アーチファクトによる影響はほとんど消失した。

14. シネ撮影系のトータルシステムパワーパフォーマン ス

\section{昭和大学病院中央放射線部 \\ ○加藤京一・中澤靖夫・新田 勝 小田正記・神田幸助}

〔目的〕シネトータルシステムは，X線系・I.I. 光学 系・現像処理系・観察系・記録系からなり，各系のパワ 一をどのように設計するかにより，画像・被曝線量に大 きな影響を与える。私たちは，シネ撮影研究会の研究成 果をもとに，新たにシネトータルシステムパワーの概念 を導入し， 2 施設のトータルシステムパワーパフォーマ ンス（以下 T.S.P.P.）を行ったので報告する.

〔方法〕 2 施設のX線出力, I.I. 光学系の出力, 現像出 力, 映写出力を求め, 比較点で得た值を T.S.P の式に代 入し，得た結果の比較検討を行う。

〔結果〕シネ撮影系の各システム出力をT.S.Pの概 念を導入することにより，分かりやすく定量的に解析で きた。

15.フーリエ級数による特性曲線近似のプーツストラッ プ法への応用

国家公務員等共済組合連合会虎の門病院 ○織田圭一・菅野由紀雄
手描きによる方法が主流であるブーツストラップ法に フーリエ級数による特性曲線近似法を応用し, 計算機に よる方法を試みた。

フーリエ級数の項数をどこまで取ると最良の結果を得 られるのか, 測定精度, 特性曲線の形等により違うので 一概には言えない，この点に問題を残しているが，手描 きによる作図法と違い個人差によるばらつきがなく，特 性曲線上から濃度や相対露光量を読み取るときの誤差も 生じず有用な方法と言える。

16. RXO シリーズと HR シリーズの現像温度特性の比 較

国家公務員等共済組合連合会虎の門病院 ○高橋順士・鈴木 斎・菅野由紀雄

〔目的〕今回，わ机れは HR シリーズと RXOシリ ーズの現像温度特性 $\left(31^{\circ} \mathrm{C}, 33^{\circ} \mathrm{C}, 35^{\circ} \mathrm{C}, 37^{\circ} \mathrm{C}\right)$ につい てそれぞれ物理的評価(特性曲線, $\bar{G}$, 感度, $D_{\max }$, カブ リ，粒状性の測定）および，視覚的評価（ハウレットチ ヤート, 限界解像力, 頭部ファントム) を試みたので報 告する。

〔結果〕 $\mathrm{RXO}-\mathrm{H} / \mathrm{G}-4$ と HR シリーズ/G-8を比較し たが，現像温度の上昇により，物理的評価の変化の割合 に優劣の差は認められなかった。視覚的評価では，現像 温度の上昇によりチャートの値が若干劣化する傾向にあ

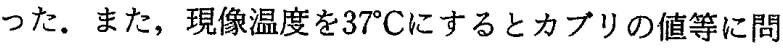
題があり，33ㄷが限界と考える。

\section{7. 大腸における注腸検査と内視鏡検查との対比}

国立東京第二病院放射線科

○小笠原哲・杉尾敏䣭

〔目的〕注腸検查の見直しのため，同一患者における 大腸内視鏡検查との結果を対比し，日常業務における内 容の確認と食い違い点を発見し，今後の注腸検査を施行 して行く上でのチェック点および改善内容等を検討した.

〔結果〕対象期間62年 1 月〜 6 月，対象数64名81所見， 年齢40〜70才代が90\%，性別男 3 ：女 2 である. 対比結 果は $40 \%$ \% 32 所見について食い違いがあり，その原因と して前処置の不良, 撮影手技, 読影違い, 注腸器具, 解 剖学的重複部位，内視鏡の見落し等が主に考えられた。

〔考察〕慣れと惰性から脱却し, 検疽結果の見直し, 検査方法の改善, 検査に取り組む姿勢を再認識すること が肝要である。

\section{座長集約}

演題11 三井記念病院, 大山らの報告は, インバー夕 制御のポータブルイメージ装置にDSA 装置を取りつけ 術中造影に使用したところ, 特に脳外科領域の手術に際 